\title{
Enterprise Combinations in Cassava Based Food Crop Farming System in Nigeria: Evidence from Ogun State
}

\author{
*Olasunkanmi M. Bamiro, Micheal Afolabi And Fisayo Daramola \\ Department of Agricultural Economics and Extension, Landmark University, \\ P.M.B. 1001, Omu-Aran, Kwara State Nigeria \\ *Corresponding Author's Email: olasunkanmibamiro1999@yahoo.co.uk
}

\begin{abstract}
This study examines the enterprise combination in cassava based food crop farming system in Ogun state. Three stage sampling technique was used to select 120 cassava farmers from the study area. The data were analyzed using descriptive statistics, economic land equivalent ratio (ELER), linear programming and stochastic production frontier to actualize all the objectives. Descriptive statistics was employed for the description of socio-economic characteristics while economic land equivalent ratio (ELER) and linear programming were used for cost-return structure and optimal combination of crops in cassava based farm enterprises respectively.

Descriptive statistics shows that most of the farmers are in their late forty with the mean age of the farmers being 48.2 years with 6years of formal education and wealth of farming experience of about 19 years. The farmers cultivated area of land that varies between 0.5 ha and 5 hectare with a mean of 2 hectare. All enterprise combinations are profitable; however, cassava/maize/vegetable production enterprise is the most profitable with net farm income of N36649.90 per hectare closely followed by cassava /maize with N36462.67 per hectare.

The optimal cassava based combination was actualized by linear programming model which shows that cassava/maize and cassava/maize/vegetable are the optimal combination because only the two combinations contributed to the gross margin and also added zero opportunity cost to the total cost of production. The result also shows that land and capital are the limiting resources whereas labour is not which means that for optimal cassava based production land and capital investment should be increased. In lieu of these findings, farmers in Ogun state farmers should intercrop cassava, maize and vegetables or intercrop cassava and maize, this will not only increase their net farm income per hectare, it will also ensure flow of income during on and off seasons. Farmers should also increase the utilization of the limiting resources, that is capital base and hectrage of land cultivated.
\end{abstract}

Keywords: Enterprise, Cassava, Farming System, Optimality, Profitability, Intercrop, Linear Programming

Introduction

Africa socio economic development is mainly agrarian and about 70 percent of the labour force and 80 percent of its poor people are directly or indirectly engaged in agriculture, live in rural area and depend on agriculture for livelihood (New partnership for African development (NEPAD), 2004). According to Olagunju 2005, agricultural sector is an engine room for sustaining growth of Nigeria economy, he also noted that agriculture still remain the mainstay of the economy of most African states, yet current estimates indicates that some 200 million or 28 percent of Africa's population are chronically hungry (Iheke, 2008).

High population growth rate which leads to increase in the demand for agricultural product, natural and human disaster such as drought, flood, land degradation as well as civil conflicts in some parts of Africa contribute to this alarming situation and account for high imports and dependence on food aids by most African countries thereby posing huge problem of food insecurity (NEPAD 2004). Cassava has been identified as a very powerful poverty fighter by driving down the price of food to millions of consumers. (Iheke 2008)

Cassava is a very important crop to Nigeria, its comparative production advantage over other staples serves to encourage its cultivation even by the resource poor farmers (Fakayode et al., 2008). Cassava production is ranked the first, followed by yam production at 27 million tonnes in 2002, sorghum at 7 million tones, millet at 6 million tones and rice at 5 million tonnes (FAO 2004). The crop's production require less labour per unit output than other major staples and crop can also thrive on relatively poor soils. International institute for tropical agriculture (2002) noted that cassava is widely grown in Africa by large numbers of small scale holders across several ecological zones because it is robust crop that can be grown under stress condition. It is also a good staple whose cultivation if encouraged can provide the nationally required food security minimum of 2400 calories per person per day (FAO 2000). 
Nigeria is the largest producers of cassava in the world; its production is currently put at about 34 million metric tonnes per year (FAO, 2004). Total harvested area of the crop in 2001 was 3.125million per hectares with an average yield of 10.83 tonnes per hectares. Nigeria cassava production is about third more than production in Brazil and almost double the respective volume of production in Indonesia and Thailand. Cassava production in other African countries who are also major producers namely Democratic Republic of Congo, Ghana, Madagascar, Mozambique, Tanzania and Uganda appears small in comparism to Nigeria substantial output (Chukwuji, 2008). At national level Benue and Kogi States in the north central zones of Nigeria are the highest producers of cassava while Cross rivers, Akwa lbom, Rivers and Delta states dominates cassava production in the south-south (FOS, 1995, IITA, 2004).

Cassava is mainly produced by small scale farmers in rural communities and is primarily produced for food especially in form of garri, fufu with little or no use in agribusiness sector as industrial raw material (Iheke, 2008), however the crop can be processed into several other product like chips, flour, pellets, adhesives, alcohol, starch etc which are raw materials in livestock, feed, alcohol/ethanol, textiles, confectionery, wood, food and soft drink industries (Iheke, 2008).

Cassava transformation has arguably proven to be the most poverty fighter till date (Nweke 2004). In Nigeria cassava is produced either as sole crop or in association with other crops in inter cropping farming systems. The predominance of this system has been occasioned by Nigeria's climate which is basically tropical and favorable for cassava production. It therefore necessary to know the most reliable number and types of enterprise combinations in order to know the most efficient combinations. Intercropping cassava with other arable crops serves as an insurance against crop failure, which may occur due to infestation of pest and disease or natural hazards, it also make available stable and steady income for the farmer. It also provide balanced diet for farming households (Unmma et al., 1989, Polson and Spencer, 1992, Okigbo 1995, Alabi and Esobhawan, 2006).

In southern ecological zones of Nigeria particularly in the southwest cassava is grown with crops like maize, melon, vegetable, yam, etc. Traditionally an average of three to five is combined (Chukwuji 2008) and best combinations to give the farmer desired result is a decision they often take by trial and error method, therefore the outcome of this study is to provide answers to which enterprise combinations would be the most profitable venture.

\section{Materials and methods}

The study area selected for this is Ogun state, Nigeria. Ogun State is situated in the tropics and covered by a land mass of 164, 0926sq kilometer. It share boundaries in the west with the Republic of Benin, east with Ondo State, and in the north with Oyo State. It is located with the rain forest belt of Nigeria with annual rainfall of 1500$2000 \mathrm{~mm}$ and a temperature of $30^{\circ} \mathrm{c}$. The climatic conditions of Ogun State results into two main seasons of dry and rainy seasons, the vegetation is a combination of forest and derived savannah supporting production of both food and cash crops like maize, cassava, yam, vegetable, oil palm, cocoa, rubber and kola nut

Ogun state is divided into four divisions namely Egba, ljebu, Remo and Yewa. Egba and ljebu divisions have 6 local government areas while Yewa and Remo divisions consists 5 and 3 local government areas respectively. Data were collected from the cassava farmers in the four divisions in the state using multistage sampling technique. The first stage involves the choice of 2 divisions, Egba and ljebu divisions based on the population of cassava farmers. The second stage involves the selection of four two local government areas from each division while the second stage was random selection of 15 farmers from each local government area resulting into a sample size of 120 .

\section{Method of data analysis}

Data were analyzed using descriptive statistics, economic land equivalent ratio (ELER), and net farm analysis. Differences in mean net farm income among enterprise combinations were separated by Fischer's least significant difference (FLSD). Descriptive statistic was employed for the analysis of the socio-economics characteristics while differences in net farm in income and Fischer's least significant differences (FLSD) were used to achieve cost and return structure of the cassava based farms. Linear programming was employed in assessing the optimal enterprise combinations in cassava based farms in the study area.

\section{Model specification}

Economic land equivalent ratio (ELER) was calculated by modification of land equivalent ratio (LER) as suggested by (Sylvia, 1999). Land equivalent ratio according to (Mead and Willey, 1980) is defined as the total land area of sole crop required to produce the same yield as would be obtained when they are intercropped.

$\operatorname{LER}=\sum\left(\mathrm{Q}_{\mathrm{m} 1} / \mathrm{Q}_{\mathrm{s} 1}\right)$. 
Where $Q_{m 1}$ is the yield of each crop in the intercrop or mixed crop farms, and $Q_{s 1}$ is the yield of each crop in sole crop farms. For each crop, the ratio is calculated to determine its partial LER and partial LER is added to give the total LER for the intercrop. An LER value of 1.0 shows no difference in yield between the intercrop and sole crop, any value greater than 1.0 indicates a yield advantage for the intercrop (Mazaheri and Oveysi, 2004, mazaheriet al., 2006).

Economic land equivalent ratio measures the ratio between the values of intercrop and sole crop; It is defined as the total land area of sole crops require to generate the same revenue as would be obtained when they are intercropped. ELER will be obtained according to (Sylvia, 1999) by multiplying the relative quantities of outputs by their unit market prices as shown below;

ELER $=\sum\left(P_{1} Q_{m 1} / P_{1} Q_{s 1}\right)=\Sigma\left(R_{m 1} / R_{s 1}\right)$.

Where $P_{1 \text { is }}$ the unit market unit selling price of ith crop and $R$ is revenue generated

\section{Linear Programming Model for Optimal Enterprise combination in cassava based crop farms}

The linear programming model employed is specified thus,

Maximize $Z=\mathrm{C}_{1} \mathrm{X}_{1}+\mathrm{C}_{2} \mathrm{X}_{2}+\ldots \ldots \ldots \ldots \ldots \ldots+\mathrm{CnXn}$

Subject to:

$A_{11} X_{1}+A_{12} X_{2}+\ldots \ldots \ldots \ldots \ldots . . . . . . . . . n X n=B_{1}$

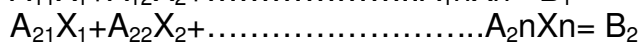

$A m_{1} X_{1}+A m_{2} X_{2}+\ldots \ldots \ldots \ldots \ldots \ldots . . . \ldots m n X n=B n$

$\mathrm{X}_{1}, \mathrm{X}_{2}, \ldots \ldots \ldots \ldots \ldots \mathrm{Xn}=0$

Where:

$\mathrm{Z}=$ The objective function (gross margin)

$\mathrm{m}=$ Number of resources

$\mathrm{n}=$ Number of activities

$X_{j}=$ Number of units of activity j,for $j=1,2, \ldots \ldots \ldots \ldots \ldots n$

$B_{i}=$ Amount of resources $I$ available for $I=1,2, \ldots \ldots \ldots \ldots . m$

$C_{j}=$ Contribution of $Z$ for each unit of activity $j$ for $j=1,2, \ldots \ldots \ldots . n$

$A_{i j}=$ Amount of ith resources consumed by each unit of activity $j$.

\section{Results and Discussion}

\section{Cost -return structure for cassava based farms}

The cost incurred and returns accrued to an average cassava based farms in the study area is presented in Table 2. The result shows that an average farmer invested $\mathbf{N 5 4 8 9 6 . 7 9}$ in the enterprise and earned $\mathrm{N} 164814.67$ as net farm income. The three profitability (gross margin, net farm income and rate of return on investment) estimated indicate that enterprises in cassava based farms are profitable. The rate of return on investment is 16.17 , implying that 16.2 percent cost of investment was realized in the enterprise.

Table 1: Cost and Return Structure of Cassava based farms

\begin{tabular}{llll}
\hline Cost & Mean & Std deviation & \%Variable cost \\
\hline cost of insecticides & 300.83 & 804.14 & 0.63 \\
Cost of pesticides & 158.33 & 1734.45 & 0.33 \\
Cost of pesticides & 2199.15 & 3987.77 & 4.63 \\
Cost of stem & 5952.88 & 3462.96 & 12.53 \\
Cost of maize seed & 669.67 & 918.18 & 1.41 \\
Cost of yam sett & 136.34 & 521.13 & 0.29 \\
Cost of melon seed & 123.17 & 515.02 & 0.26 \\
Cost of corm & 85.17 & 299.52 & 0.18 \\
Cost of vegetable seed & 229.76 & 532.06 & 0.48 \\
Labour cost & 35813.33 & 20961.84 & 75.39 \\
Transport cost & 1835.83 & 2080.63 & 3.86 \\
Total variable cost & $\mathbf{4 5 7 7 1 . 5 8}$ & $\mathbf{2 7 6 4 4 . 0 1}$ & \\
Cost of land & 3702.08 & 25196.36 &
\end{tabular}


Table 1: Continues

\begin{tabular}{|c|c|c|c|}
\hline Total fixed cost & 9125.21 & 26090.69 & \\
\hline Total cost & 54896,79 & 40769.18 & \\
\hline Returns & & & \%Revenue \\
\hline revenue from cassava & 87937.92 & 58092.77 & 79.2 \\
\hline revenue from maize & 14867.08 & 23457.55 & 13.44 \\
\hline revenue from yam & 1400 & 6154.04 & 1.27 \\
\hline revenue from melon & 1651.25 & 4429.18 & 1.49 \\
\hline $\begin{array}{ll}\text { revenue } & \text { from } \\
\text { vegetable } & \end{array}$ & 3738.33 & 8976.77 & 3.38 \\
\hline revenue from cocoyam & 991.67 & 3727.67 & 0.90 \\
\hline Total revenue & 110586.25 & 73481.54 & \\
\hline Gross margin & 64814.67 & 54379.70 & \\
\hline Net margin & 55689.46 & 49597.99 & \\
\hline Rate of return & 16.17 & 35.23 & \\
\hline
\end{tabular}

Source: Computed From Field Survey, 2010

\section{Summary of Statistics of Variables for all cassava farmers}

The statistics of the socio-economic variables for cassava farmers are presented in Table 3 . The result shows that the farmers are aged between 28 to 70 with mean age of 48.2 years. Educationally they spent $0-16$ years acquiring formal education with mean of 5.9 years, with farmers having as high as 41 years of farming experience. The respondents are small scale farmers with their farm size ranging from $0.5-5$ hectares of land. Expenses on labour, capital and rent on land/ hectares are $\mathbf{N 1 8 8 0 1 . 3 6 1 , ~} \mathbf{N} 30065.278, \mathrm{~A} 1312.5$ respectively, this shows that cassava based farm is more capital intensive than labour. The mean value of output/ hectares, net farm income/ hectares and percentage on investment are-N55422.132, N26873.885 and 16.2 percent respectively.

Table 2: Summary Of Statistics Of All Variables For All Respondents

\begin{tabular}{|c|c|c|c|c|}
\hline Variables & Mean & $\begin{array}{l}\text { Standard } \\
\text { Deviation }\end{array}$ & Minimum & Maximum \\
\hline Age in yrs & 48.2 & 11.36 & 28 & 70 \\
\hline Education in yrs & 5.9 & 0.37 & 0.0 & 16 \\
\hline Farming exp (yrs) & 18.6 & 10.24 & 3 & 41 \\
\hline Farm size (ha) & 2.0 & 1.05 & 0.5 & 5 \\
\hline Labour/ha (\#) & 18801.36 & 8069.97 & 8050 & 64000 \\
\hline Capital/ha(N) & 30065.278 & 10590.38 & 15000 & 65080 \\
\hline Rent/ha(A) & 1312.50 & 7117.18 & 0.0 & 6000 \\
\hline $\begin{array}{l}\text { Output } \\
\text { value/ha(\#) }\end{array}$ & 55422.132 & 16864.21 & 27000 & 104500 \\
\hline $\begin{array}{l}\text { Netfarm } \\
\text { income/ha(A) }\end{array}$ & 26873.885 & 14362.60 & -25675 & 67850 \\
\hline $\begin{array}{l}\text { Return on } \\
\text { investment (\%) }\end{array}$ & 16.17 & 35.23 & 1.55 & 367.11 \\
\hline
\end{tabular}

Source: Computed From Field Survey, 2010

Enterprise combination of cost and return in Cassava based farming using Economic Land Equivalent Ratio (ELER)

The revenue, economic land equivalent ratio (ELER), cost and net farm income analysis of the farmers by their different numbers and types of enterprise combinations are presented in Table 4. In terms of number of enterprises, two enterprise combinations (Cassava/Maize and Cassava only) are the most popular in the study area with about $33 \%$ of the sampled farmers combining cassava and maize, about $18 \%$ of them planting cassava only while $12 \%$ and $10 \%$ of the sampled farmers intercropped cassava and vegetable and cassava and melon 
respectively. The economic land equivalent ratio range from 1.00 in cassava sole cropping to 1.74 in cassava/ maize/ melon enterprise, this shows that all forms of enterprise combinations in cassava based food crop farming system in the area has higher land equivalent ratio than cassava sole cropping, however cassava sole cropping produced higher net farm income per hectare than some combinations in the study area which implies that cassava sole cropping is more profitable than some of the enterprise combinations.

The result further shows that combining three enterprises significantly generated the highest net farm income with cassava/ maize /vegetable enterprise giving the highest of about N36649.99 per hectares, which is closely

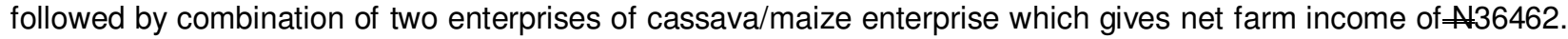
Cassava/melon/vegetable enterprise produced the least net farm income of all the enterprise combinations with a mean meager net farm income of $\mathbf{N 1 3 1 8 0 .}$

Table 3: Enterprise Combinations Of Cost and Return in Cassava-Based Farming Using Economic Land Equivalent Ratio (ELER)

\begin{tabular}{|c|c|c|c|c|c|}
\hline Crop mixture & Number & Gm/ha & ELER & TC/ha & Fl/ha \\
\hline Cassava/maize & $40(33.3)$ & 72179.38 & 1.31 & 35716.70 & $36462.67^{0}$ \\
\hline $\begin{array}{l}\text { Cassava/vegetable } \\
\text { Cassava/yam }\end{array}$ & $\begin{array}{l}14(11.7) \\
7(5.8)\end{array}$ & $\begin{array}{l}43760.60 \\
40964.29\end{array}$ & $\begin{array}{l}1.35 \\
1.36\end{array}$ & $\begin{array}{l}26686.27 \\
22597.50\end{array}$ & $\begin{array}{l}17074.32^{\mathrm{ab}} \\
18366.79^{\mathrm{ab}}\end{array}$ \\
\hline $\begin{array}{l}\text { Cassava/melon } \\
\text { Cassava/cocoyam }\end{array}$ & $\begin{array}{l}12(10) \\
6(5)\end{array}$ & $\begin{array}{l}44214.93 \\
35808.33\end{array}$ & $\begin{array}{l}1.17 \\
1.26\end{array}$ & $\begin{array}{l}22883.26 \\
19714.17\end{array}$ & $\begin{array}{l}21331.67^{\mathrm{ab}} \\
16094.77^{\mathrm{ab}}\end{array}$ \\
\hline Cassava/maize/vegetable & $8(6.7)$ & 58332.29 & 1.59 & 21682.40 & $36649.90^{\mathrm{D}}$ \\
\hline Cassava/maize/cocoyam & $3(2.5)$ & 48284.44 & 1.57 & 24826.22 & $23458.22^{a b}$ \\
\hline $\begin{array}{l}\text { Cassava/maize/melon } \\
\text { Cassava/maize/yam } \\
\text { Cassava/yam/melon }\end{array}$ & $\begin{array}{l}2(1.7) \\
3(2.5) \\
2(1.7)\end{array}$ & $\begin{array}{l}44854.17 \\
55761.11 \\
33725.00\end{array}$ & $\begin{array}{l}1.74 \\
1.42 \\
1.55\end{array}$ & $\begin{array}{l}20536.25 \\
29736.94 \\
20256.67\end{array}$ & $\begin{array}{l}24317.92^{\mathrm{ab}} \\
26024.77^{\mathrm{ab}} \\
13468.33^{\mathrm{a}}\end{array}$ \\
\hline Cassava/melon/vegetable & $1(0.8)$ & 36916.67 & 1.29 & 23736.67 & $13180.00^{\mathrm{a}}$ \\
\hline Cassava/maize/melon/coc & $1(0.8)$ & 42625.00 & 1.52 & 24565.00 & $18060.00^{\mathrm{ab}}$ \\
\hline Cassava only & $21(17.5)$ & 52531.35 & 1.00 & 28829.09 & $23702.26^{a b}$ \\
\hline
\end{tabular}

Means with the same superscript are not significantly different

Source: computed from field survey,

Optimal combinations of crops in cassava based farms.

The optimality with respect to crop farming enterprises are analyzed with aid of linear programming model, The simplex tableau is presented in Table 5.

Table 4 Linear Programming Matrix of Cassava based farm enterprises

\begin{tabular}{|c|c|c|c|c|c|c|c|c|c|c|c|c|c|c|}
\hline & $\begin{array}{l}\mathrm{Ca} \\
\left(\mathrm{X}_{1}\right)\end{array}$ & $\begin{array}{l}\mathrm{Ca} / \mathrm{ma} \\
\left(\mathrm{X}_{2}\right)\end{array}$ & $\begin{array}{l}\mathrm{Ca} / \mathrm{ve} \\
\left(\mathrm{X}_{3}\right)\end{array}$ & $\begin{array}{l}\mathrm{Ca} / \mathrm{ya} \\
\left(\mathrm{X}_{4}\right)\end{array}$ & $\begin{array}{l}\mathrm{Ca} / \mathrm{me} \\
\left(\mathrm{X}_{5}\right)\end{array}$ & $\begin{array}{l}\mathrm{Ca} / \mathrm{co} \\
\left(\mathrm{X}_{6}\right)\end{array}$ & $\begin{array}{l}\mathrm{Ca} / \\
\mathrm{ma} / \mathrm{ve} \\
\left(\mathrm{X}_{7}\right)\end{array}$ & $\begin{array}{l}\mathrm{Ca} / \\
\mathrm{ma} / \mathrm{co} \\
\left(\mathrm{X}_{8}\right)\end{array}$ & $\begin{array}{l}\mathrm{Ca} / \\
\mathrm{ma} / \\
\mathrm{me} \\
\left(\mathrm{X}_{9}\right)\end{array}$ & $\begin{array}{l}\mathrm{Ca} / \\
\mathrm{ma} / \\
\text { yam } \\
\left(\mathrm{X}_{10}\right)\end{array}$ & $\begin{array}{l}\mathrm{Ca} / \mathrm{ya} / \\
\mathrm{Ma} \\
\left(\mathrm{X}_{11}\right)\end{array}$ & $\begin{array}{l}\mathrm{Ca} / \\
\mathrm{me} / \mathrm{ve} \\
\left(\mathrm{X}_{12}\right)\end{array}$ & $\begin{array}{l}\mathrm{Ca} / \\
\mathrm{ma} / \\
\mathrm{Me} / \mathrm{co} \\
\left(\mathrm{X}_{13}\right)\end{array}$ & \\
\hline $\begin{array}{l}\text { Maximize } \\
\text { subject to }\end{array}$ & 28314 & 41662 & 24845 & 21193 & 25079 & 19618 & 38785 & 26590 & 26228 & 29458 & 15728 & 15000 & 21110 & \\
\hline Land & 1.0 & 1.0 & 1.0 & 1.0 & 1.0 & 1.0 & 1.0 & 1.0 & 1.0 & 1.0 & 1.0 & 1.0 & 1.0 & $=5.0$ \\
\hline Labour & 99.0 & 117.0 & 76.0 & 89.0 & 83.0 & 104.0 & 110.0 & 48.0 & 83.0 & 78.0 & 99.0 & 41.0 & 87.0 & $=827$ \\
\hline Capital & 31937 & 36529 & 25324 & 24000 & 24826 & 20611 & 28542 & 26933 & 20000 & 30833 & 20333 & 23333 & 26250 & $=180000$ \\
\hline
\end{tabular}

Source: computed from field survey, 2010 
MaximizeZ

$=28314 X_{1}+41662 X_{2}+24845 X_{3}+21193 X_{4}+25079 X_{5}+19618 X_{6}+38785 X_{7}+26590 X 8+26228 X_{9}+29458 X_{10}+15728 X_{11}+$ $15000 X_{12}+21110 X_{13}$

Subject to

$\mathrm{X}_{1}+\mathrm{X}_{2}+\mathrm{X}_{3}+\mathrm{X}_{4}+\mathrm{X}_{5}+\mathrm{X}_{6}+\mathrm{X}_{7}+\mathrm{X}_{8}+\mathrm{X}_{9}+\mathrm{X}_{10}+\mathrm{X}_{11}+\mathrm{X}_{12}+\mathrm{X}_{13} \leq 5$ (land)

$99 X_{1}+117 X_{2}+76 X_{3}+89 X_{4}+83 X_{5}+104 X_{6}+110 X_{7}+48 X_{8}+83 X_{9}+78 X_{10}+99 X_{11}+41 X_{12}+87 X_{13} \leq 827$ (Labour)

$31937 X_{1}+3652 X_{2}+25324 X_{3}+24000 X_{4}+24826 X_{5}+20611 X_{6}+28542 X_{7}+26933 X_{8}+20000 X_{9}+30833 X_{10}+20333 X_{11}+233$

$33 \mathrm{X}_{12}+26250 \mathrm{X}_{13} \leq 180000$ (Capital)

The linear programming model was constructed based on the 13 identified cassava based combinations of food crops in the area. The matrix shows the enterprises' gross margin, the available resources and the used resources.

The result shows that only enterprises $X_{2}$ (cassava and maize) and $X_{7}$ (cassava, maize and vegetable) entered the final crop solution. The optimal value of the programme is $\# 207357.24$; (that is $\$ 41471.45 \mathrm{ha}^{-1}$ ) this is the value of the programme which was obtained by cultivating 4.67 hectares of land for cassava and maize and 0.33 hectares of land for intercropping of cassava, maize and vegetable at a gross margin of \#194513.08 ( $\$ 41651.62 \mathrm{ha}^{-1}$ and $\$ 12844.16\left(\$ 38921.70 \mathrm{ha}^{-1}\right)$ respectively.

Table 5: Linear Programming Solution for Cassava based farms

OBJECTIVE VALUE $=207357$

\begin{tabular}{llll}
\hline Variable & Value & Objective coefficient & $\begin{array}{l}\text { Objective } \\
\text { value contribution }\end{array}$ \\
\hline Cassava only $\left(\mathrm{X}_{1}\right)$ & & & 0.0 \\
Cassava/maize $\left(\mathrm{X}_{2}\right)$ & 0.0 & 28314.0 & 194513.08 \\
Cassava/vegetable $\left(\mathrm{X}_{3}\right)$ & 4.67 & 41662.0 & 0.0 \\
Cassava/yam $\left(\mathrm{X}_{4}\right)$ & 0.0 & 24845.0 & 0.0 \\
Cassava/melon $\left(\mathrm{X}_{5}\right)$ & 0.0 & 21193.0 & 0.0 \\
Cassava/cocoyam $\left(\mathrm{X}_{6}\right)$ & 0.0 & 25079.0 & 0.0 \\
Cassava/maize/vegetable $\left(\mathrm{X}_{7}\right)$ & 0.0 & 19618.0 & 12844.16 \\
Cassava/maize/cocoyam $\left(\mathrm{X}_{8}\right)$ & 0.33 & 38785.0 & 0.0 \\
Cassava/maize/melon $\left(\mathrm{X}_{9}\right)$ & 0.0 & 26590.0 & 0.0 \\
Cassava/maize/yam $\left(\mathrm{X}_{10}\right)$ & 0.0 & 26228.0 & 0.0 \\
Cassava/yam/melon $\left(\mathrm{X}_{11}\right)$ & 0.0 & 29458.0 & 0.0 \\
Cassava/melon vegetable $\left(\mathrm{X}_{12}\right)$ & 0.0 & 15728.0 & 0.0 \\
Cassava/maize/melon/vegetable $\left(\mathrm{X}_{13}\right)$ & 0.0 & 15000.0 & 0.0 \\
Constraint & 0.0 & 21110.0 & \\
Land $(<)$ & $\mathrm{RHS}$ & Slack-/surplus+ & \\
Labour $(<)$ & 5.0 & 0.0 & \\
\hline Capital $(<)$ & 827.0 & $244.32-$ & \\
\hline Source: & $\mathbf{1 8 0 0 0 0}$ & $\mathbf{0 . 0}$ & \\
\hline
\end{tabular}

Source: computed from field survey, 2010.

The final iteration in Table 6 shows that 1 1enterprises, $X_{1}, X_{3}, X_{4}, X_{5}, X_{6}, X_{8}, X_{9}, X_{10}, X_{11}, X_{12}$ and $X_{13}$ did not enter the final plan, since they have non-zero opportunity cost indicating that these enterprises are not in the best competitive positions as compared to enterprises $\mathrm{X}_{2}$ and $\mathrm{X}_{7}$.

TABLE 6 Opportunity Cost of Enterprises and resources in Cassava based farms

\begin{tabular}{|c|c|c|c|c|}
\hline Variable & Current objcoeff & Min objcoeff & Max objcoeff & Reduced cost \\
\hline $\mathrm{X}_{1}$ & 28314.0 & -infinity & 40007.91 & 11693.91 \\
\hline$X_{2}$ & 41662.0 & 38785.0 & 49638.33 & 0.0 \\
\hline$X_{3}$ & 24845.0 & -infinity & 37625.84 & 12780.84 \\
\hline$X_{4}$ & 21193.0 & -infinity & 37148.92 & 15955.92 \\
\hline$X_{5}$ & 25079.0 & -infinity & 37446.46 & 12367.46 \\
\hline$X_{6}$ & 19618.0 & -infinity & 35928.17 & 16310.17 \\
\hline$X_{7}$ & 38785.0 & 34204.12 & 41662.00 & 0.0 \\
\hline$X_{8}$ & 26590.0 & -infinity & 38205.42 & 11615.42 \\
\hline $\mathrm{X}_{9}$ & 26228.0 & -infinity & 35708.08 & 9480.08 \\
\hline$X_{10}$ & 29458.0 & -infinity & 39610.24 & 10152.24 \\
\hline $\mathrm{X}_{11}$ & 15728.0 & -infinity & 35828.03 & 20100.03 \\
\hline
\end{tabular}


Table 6: Continues

\begin{tabular}{lllll}
\hline $\mathrm{X}_{12}$ & 15000.0 & -infinity & 36908.66 & 21908.66 \\
$\mathrm{X}_{13}$ & 21110.0 & -infinity & 37959.40 & 16849.40 \\
Constraint & Current RHS & Min RHS & Max RHS & Dual price \\
Land $(<)$ & 5.0 & 4.93 & 6.31 & 28503.88 \\
Labour $(<)$ & 827.0 & 582.68 & Infinity & 0.00 \\
\hline Capital $(<)$ & $\mathbf{1 8 0 0 0 0}$ & $\mathbf{1 4 2 7 1 0}$ & $\mathbf{1 8 2 6 4 5 . 0 0}$ & $\mathbf{0 . 3 6}$ \\
\hline
\end{tabular}

This result shows that the best/optimal enterprise combination which is capable of maximizing net farm income in cassava based farming in the study area is cassava and maize and cassava maize and vegetable enterprise.

The result in Table 7 shows that the opportunity cost of the excluded enterprises are 11693.91 for

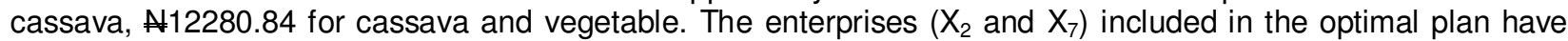
zero opportunity cost, this result indicates that any of the enterprise that are excluded from the plan, the value of the programme would be reduced. For example, forcing $X_{1}$ (cassava only) into the plan, the value of the programme will reduce by $\mathrm{N} 11693.91$, this is similar for other excluded variables. Opportunity cost of resources used in cassava based farming in the area indicates that land and capital are the limiting resources while labour is a non-limiting resource in the area, there are $\mathbf{2 4 4 . 3 2}$ man days of labour that are needed. The shadow price of land was $\mathrm{N} 28503.88$ indicating that by increasing the size of land in hectares available, the gross margin would increase by 28503.88 . Also the shadow price of capital is 36 kobo indicating that by increasing capital investment by $\mathrm{N} 1$, the gross margin would increase by 36 kobo.

The results further indicate that for optimal cassava based combinations land and capital resources should be increased since labour is not limited. Increased hectares of land and naira investment therefore, would lead to increases in cassava based farming in the area.

\section{Conclusion}

This study examines the enterprise combination in cassava based food crop farming system in Ogun state. Three stage sampling technique was used to draft cassava farmers from the study area, and a total of hundred and twenty farmers were selected. Data were collected on socio economic characteristics; cost and return associated with cassava based farming system and crop combination. The data were analyzed using descriptive statistics, economic land equivalent ratio (ELER), linear programming and stochastic production frontier to actualize all the objectives. Descriptive statistics was employed for the description of socio-economic characteristics while economic land equivalent ratio (ELER) and linear programming were used for cost-return structure and optimal combination of crops in cassava based farm enterprises respectively.

Descriptive statistics shows that most of the farmers are in their late forty with the mean age of the farmers being 48.2 years with 6years of formal education and wealth of farming experience of about 19 years. The farmers cultivated area of land that varies between $0.5 \mathrm{ha}$ and 5 hectare with a mean of 2 hectare. The cost return structure obtained via economic land equivalent ratio (ELER) shows that cassava/maize/vegetable are the most profitable by having the same level of significance when Fishers least significant difference was used to separate the means of different enterprise. All enterprise combinations are profitable; however, cassava/maize/vegetable production enterprise is the most profitable with net farm income of $\$ 36649.90$ per hectare closely followed by cassava /maize with $\$ 36462.67$ per hectare.

The optimal cassava based combination was actualized by linear programming model which shows that cassava/maize and cassava/maize/vegetable are the optimal combination because only the two combinations contributed to the gross margin and also added zero opportunity cost to the total cost of production. The result also shows that land and capital are the limiting resources whereas labour is not which means that for optimal cassava based production land and capital investment should be increased.

In lieu of these findings, farmers in Ogun state farmers should intercrop cassava, maize and vegetables or intercrop cassava and maize, this will not only increase their net farm income per hectare, it will also guarantee flow of income throughout the year. Furthermore, the farmers should endeavor to increase the utilization of the limiting resources, that is increase their capital base and hectare of land that will be allocated to cassava based enterprises in the subsequent seasons. 


\section{REFFERENCES}

Alabi R.A and Esobhawan A.O (2006); relative economic value of maize -okra intercrops in rain forest zone of Nigeria. Journal of central European agriculture.7 (3): 433-438

BabatundeR.O,Olorunsanya E.O. Orebiyi J.S, Falola A, Optimal Farm Plan in Potato Cropping Systems; The Case of Offa and Oyun Local Government Areas of Kwara State, North Central. Nigeria Agricultural Journal 2 (2); $285-289,2007$.

Bravo-Ureta and A.E.Pinheiro,(1993).efficiency analysis of developing countries agriculture; A review of the frontier literature. Agric. Resoure.Econ. Rev., 22:88-101.

Central bank of Nigeria (CBN) (2002);Annual Report and statement of account, CBN Abuja, Nigeria.

Chukwuji O.C (2008); Comparative analysis of enterprise combination cost and return in cassava based food crop farming system in Delta state Nigeria. Jounal of Agricultural and biological science page 27- 31.

COSCA (1996). Collaborative Study of Casaava in Africa International institute of tropical Agriculture (IITA) Ibadan, Nigeria.

Fakayode S.B, Babatunde R.O and Ajao.R (2008); Productivity analysis of cassava based production systems in guinea savannah.American-Eurasian Journal of Scientific Research 3 (1):33-39.2008

Food and Agriculture Organization (FAO) (2000); agriculture towards 2010/30 technical interim report April 2000 Rome.

Food and agriculture organization( FAO) (2004), online statistical data base Rome, Italy; food and agriculture organization of the united nations.

IhekeOnwucheka Raphael (2008): Technical efficiency of cassava farmers in South Eastern Nigeria. Agricultural Journal 3 (2): 152-156, 2008

IITA (2004). Nigeria cassava industry: statistical Handbook, Ibadan, Nigeria

IITA (2002); Competiveness workshop Oportunity in Nigeria Bokanga, IITA Ibadan.

Ijeoma E, (2004) NEPAD Pan African Cassava Initiatives new Partnership for African Development.

Kawano (2003). Thirty Years of cassava Breeding for Productivity- Biotechnology and Social Factors for Success. Crop science 43/4:1325 - 1335 .

Nweke F.I.(1999) cassava production in Nigeria: A function of farmer Access to Markets and to Improved Production and Processing Technologies. Collaborative Study of cassava Africa.

Nweke F.I ( 1997); cassava is a cash crop in Africa, A view point, IITA research number 14/15:26-27.

Oke,O.L.2005: Cassava Yesterday,Today and Tomorrow Ife Lectures Series number 7, The post graduate Lectures Series, ObafemiAwolowoUnversity, Ile Ife, Nigeria

Olagunju G, (2005) Turning Farming into goldmine; An Evaluation of the Presidential Initiatives on cassava. http//:www.nigeriafirst.org.

Onyenweaku C.E. and D.O. Ohajianya, (2005). Technical efficiency of swamp and upland rice farms in south eastern Nigeria. J. Sust Trop. Agric. Res., 14: 64-70

Onyenweaku C.E., K.C.Igwe and J.A.Mbanasor(,2004).Application of Stochastic Frontier in the Measurement of technical efficiency in Yam production in Nassarawa state, Nigeria. J. Sust. Trop. Agric. Res., pp:13.

Osibo (2007): Research for Development;from Basic to End - User - Drivers Approaches for Driving out poverty and Nourishing Africa. Agrilink business Day 24/04/2007.

Polson R.A and Spencer D.S.C (1992). The technology adoption process in subsistence agriculture: The case of South Eastern Nigeria IITA research. (5): 12-16.

Scott G.J. Rosegrant, M.W. \& Ringer C. (2000): Root and Tuber for the $21^{\text {st }}$ Century Trends. IFPRI Washinton DC projection and policy for developing countries.

Shaib, Bukar, AdamuAliyu\&Bakshi J.S (1997), Nigeria National Agricultural Research Strategy Plan 1996-2010 Ibadan Nigeria Intech Printers Limited.

Taylor, T.G. and J.S. Shinkwiler, (1986). Alternative Stochastic Specifications of the Frontier Production Function in the analysis of Agricultural Credit Programmes and Technical Efficiency .Dev. Econ., 21:149-160.

Technical for Agricultural and Rural Cooperation (CTA),( 2005).Cooperation for Agricultural Development in ACP countries. SPORE 118. August,2005. 